\title{
Corporate Inversions: The Migration Of Corporate Tax Revenue
}

\author{
Joel Barker, Borough of Manhattan Community College, CUNY, USA
}

\begin{abstract}
Estimates of over 20 billion of tax revenue are lost to our economy because of corporate inversions. Therefore, lawmakers are actively exploring ways to stop the hemorrhaging of corporate tax-revenues, tighten restrictions on corporate inversions, and to find ways to collect on defer tax revenues. From a business prospective, corporate inversions are nothing less than prudent, innovative, business strategies to enhance corporate profits. However, it's undoubtedly having a significant impact on U.S. tax revenues and ultimately reducing domestic investments. Ireland is now the most popular new home to many U.S. Corporations, especially within the pharmaceutical industry. The advantageous tax incentives offered by Ireland is a "no-brainer," when compared to the heavy taxes levied upon domestic business. Since the Tax Reform Act of 1986, there has been no major tax reform to the United States Tax System. Despite the various proposals and recommendations made to address this growing economic issue, all concern parties are in consensus that the United States Tax System needs reform.
\end{abstract}

Keywords: Corporate Inversion; Tax Avoidance; Tax Erosion; Tax Reform

\section{INTRODUCTION}

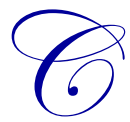

orporations' tax is the third largest source of federal revenues and approximately $2 \%$ of the U.S. Gross Domestic Product (GDP). Over the years, this source of revenue is diminishing due to corporate inversions. Multinational Corporations whose parent companies are base in the U.S. are migrating to foreign jurisdictions that provide significant tax incentives, along with other fringe benefits.

Companies involved in inversions, have never disclosed that tax incentives were their primarily reason for migrating. Rather, the reasons included to stakeholders were, operational flexibility, enhancing cash management, and access to international capital markets. The tax incentives incurred are merely "coincidental benefits of prudent business decisions."

Multinational corporations, whose parent subsidiary resides in the United States, primary practice corporate inversions. It's a win-win situation for the U.S. Corporations and the foreign countries to which they migrate. The U.S. Corporations benefits greatly with tax-savings and the foreign countries benefits with large capital inflows and investments, thus stimulating their economy. Over the last decade, some of the high-profiled multinational companies that have expatriated were Burger King, Ingersoll-Rand, Coopers Industries, Foster, PXRE Group, and Nabors Industries. According to Bloomberg Business website, in an article titled "Tracking Tax Runaways," companies like Cyberonics Inc., Wright Medical Group Inc., Steris Corp., and Civeo Corp. are still pending inversion as of April $13^{\text {th }} 2015$.

For the purpose of this article, we will explore what are Corporate Inversions, what impacts it has on the U.S. economy, what roles CPAs play, and what preventative measures are available to combat this issue?

\section{What is Corporate Inversions?}

Corporate inversion is a business transaction, which occurs when a U.S. base multinational corporation restructures in such a way that it creates a new domicile in a foreign jurisdiction, to avoid U.S. taxes. Corporate Inversion occurs through three different paths: the substantial activity test, merger with a larger foreign firm, and merger with a smaller foreign firm. Despite the method used, and the reasons noted by the U.S. Corporations, the result is that the 
new foreign parent company exists in a jurisdiction with a lower tax rate and little-to-no taxes on the company's foreign-source income.

\section{The Substantial Activity Path}

This type of inversion is typically form when a domestic corporation and a foreign corporation engages in large substantial business activities, they decide to acquire ownership interest in each other. These interests are acquired through the exchanging of a domestic corporation's stocks for that of the foreign corporation stocks. The exchange is generally in proportionate to each corporation's respective valuation. Since no change in the effective control of the domestic corporation occurs, it is generally referred to as a "naked inversion."

\section{Merger with a Larger Foreign Firm}

In this form of inversion, a U.S. corporation merges with a larger foreign corporation, who maintains the controlling interest. While these mergers are primarily driven by business considerations (for example, to gain market advantage by boosting foreign operations), a tax-incentive element is always present. After the merger, a new foreign corporation emerges with U.S. shareholders owning a minority share of the new company. An example of such a merger existed between U.S. Corporation Pride, and UK firm, Ensco. During the recommendation of the approval of that merger, Pride's board of director stated that the merger was in part because, “... Ensco was headquartered in a jurisdiction that has a favorable tax regime and an extensive network of tax treaties, which can allow the combined company to achieve a global effective tax rate comparable to Pride's competitors ${ }^{\mathrm{i}}$."

\section{Merger with a Smaller Foreign Firm}

This form of inversion occurs in principle just as inversions created through the merger with larger foreign corporations, except the U.S. Corporation targets a smaller foreign owned corporation to merge with and retains majority interest of the new merged company. That is to say, U.S. shareholders have controlling interest in the new foreign-based company. An example of such an inversion is the merger between U.S. Corporation Eaton and Irish company Cooper. The acquisition of Cooper created a tax-incentive of a tax rate of only $12.5 \%$ under the territorial tax system in Ireland. Another example is Burger King who relocated to Canada, where the corporate tax rate is only $15 \%$.

\section{Taxation on U.S. Corporation}

The United States tax system includes taxing both the worldwide income of domestic corporations and the income of foreign firms' earnings within U.S. territory. All income earned domestically is taxed the same-in the year earned. Corporations are tax at a statutory rate of up to $35 \%$ on both worldwide and domestic income. Not all income earned however, is taxed within the year earned. Some corporations can defer taxes on income earned abroad in foreign subsidiaries until it is paid, or repatriated, to the U.S. parent company as a dividend. To avoid the issue of double taxation on repatriated funds or dividends, the Internal Revenue Code has provided a safety net by implementing the foreign tax credit. Taxation on passive income such as interest, dividends, annuities, rents, and royalties earned by certain foreign subsidiaries, generally are tax in the year earned.

Income that does not qualify for deferral is "subpart F income." Subpart F income generally includes passive types of income such as interest, dividends, annuities, rents, and royalties. ${ }^{i i}$ U.S. Corporations must pay taxes on subpart F income in the year earned, regardless if it was actually repatriate to the United States. Active financing incomes, such as income from operations in banking, financing, and insurance industry, are an exception to the subpart F income tax rules.

\section{Avoiding U.S. Taxation}

As the saying often goes, "the stricter the government, the wiser the population," corporations continues to explore ways to avoid the burden of U.S. high levied "tax-arm." Over the years, domestic corporations to avoid paying their tax liabilities have explored many strategies. However, over the last decade, corporate inversions have become more prevalent and seen by many as tax avoidance schemes, rather than prudent business decisions. 
The current tax situation allows corporations to defer taxation of certain foreign revenues until repatriated back to the United States. However, corporations are in no hurry to return those funds to the U.S. because of the "tax-axe" that awaits those earnings. U.S. Corporations' foreign coffers continue to grow and remain outside U.S. taxing authorities. Not only have U.S. corporations denied the IRS tax revenues on those funds, but also they have created yet another loophole that further decreases the collectability of corporate tax revenues.

Many large multinational companies have shift their reported income from the U.S. to low-tax-territories like, Ireland, The United Kingdom, and Japan, by manipulating interest expenses and other fixed costs to domestic operations. Another manner in which such manipulations occur is within intercompany transfer pricing. Intercompany transfer pricing, refers to the prices company charge their subsidiaries and affiliate. Companies would sell assets to their subsidiaries very cheap, while buying other assets from subsidiaries very expensive (income smoothing practices). Intangible assets such as patents, trademarks, and others, are very difficult for taxing authorities to determine what prices would constitute arms-length transactions (the IRS requires that intercompany transfer pricing should represent that of a genuine business transaction, that is to say, the price affiliated companies are charging each other should reflect the market price charged to a non-affiliated customer) and therefore many companies uses this has a loophole to further erode domestic tax base.

Based upon data provided by The Ways and Means Committee, over the last five years $(2010-2014), 52 \%$ of the companies inverted to Ireland and 19\% to The United Kingdom. The United Kingdom is one of the last countries to attract corporate inversion. Some of the multinational corporations that have created new domiciles in countries like Ireland, Switzerland, and The United Kingdom, didn't stay there long, but rather inverted again to countries like Bermuda and the Cayman Island because of their no-corporation-tax-policies.

The latest ongoing high profiled case of inversion is the attempt by the pharmaceutical giant Pfizer to acquire AstraZeneca, and make Ireland their tax domicile. This proposed inversion would have sparked many debates and discussions by lawmakers and political figures. The Department of Treasury intervened, along with other agencies to block the merger. The merger meant a significant potential loss of tax revenues of an estimated 1.4 billion per year. Chief Executive Officer of Pfizer Inc., Ian Read, defends his company's actions as "the best strategy to help shareholders." Critics have deemed their business venture a creative way to shelter future earnings from U.S. taxation through earnings stripping. According to Rubin, Baigorri, and David, Pfizer has as much of 30 billion in offshore cash and investments. During 2005, when a temporary tax exclusion of $85 \%$ of repatriated funds (dividends) was enforced, Pfizer seized the opportunity and repatriated 37 billion in funds. This resulted in over 31 billion in tax savings for Pfizer.

Despite the controversies surrounding Pfizer's intent to migrate to Ireland, Pfizer is currently embarking on a 160 billion deal to merge with Allegan. Unlike their attempt to acquire AstraZeneca, this deal does not appear to violate any tax laws.

\section{Combating Tax Erosion and Corporate Inversion}

Estimates of over 20 billion of tax revenue are lost to our economy because of corporate inversions. Therefore lawmakers are actively exploring ways to stop the hemorrhaging of corporate tax-revenues, tighten restrictions on corporate inversions, and to find ways to collect on defer tax revenues.

President Obama in his 2016 fiscal budget target ways to combat this problem by proposing a one-time tax of $14 \%$ on the estimated 2.1 trillion in accumulated earnings in foreign coffers kept by multinational corporations like GE, Microsoft, Pfizer, and Apple. The implementation of $14 \%$ on foreign earnings can raise an estimated 238 billion in tax revenues, for repairs and improvement of roads, bridges, and the transit system in the United States.

The President also proposed that moving forward; he will lower the tax rate of foreign earnings from $35 \%$ to $19 \%$, thus removing the loophole that currently allows corporations to defer taxation on these earnings. ${ }^{\text {iii }}$ Despite the fact that the tax revenue gap is widening, some critics believe that corporations shouldn't be punish for making prudent business decisions created by the high taxed levied upon them. Obviously, there are and will continue to be discussions in favor and against corporate taxation. 
President Obama in his State of the Union address also mentioned the economic impact of corporate inversions and the need to "eliminate unfair and inefficient loopholes." Some ways he mentioned to achieve that, is to lower corporate tax rate from $35 \%$ to $28 \%$, lowering domestic manufacturing tax rate to $25 \%$ (which inadvertently will foster domestic investment), tighten up on rules that allow firms to use accounting techniques like income shifting to avoid U.S. taxation. The president also highlighted the need to support small business by creating tax incentives (small businesses will have the ability to deduct up to 1 million in investment expenses, annually), since they employ half the United States work force and generate almost half the U.S. Gross Domestic Product (GDP). ${ }^{\text {iv }}$

Critics and lawmakers have recommended the implementation of a territorial tax system to give the U.S. competitiveness in the tax-market. However, what is to say, that if the U.S. adopt such a system, and cut tax rates to compete in the tax market, that Europe and other countries will not respond by offering even further incentives for U.S. Corporations to migrate. History have proven that after the implementation of the Tax Reform Act of 1986, which significantly reduced corporate tax rates by $14 \%$, that other countries reacted to this tax change by lowering their corporate tax rates. What is to prevent the occurrence of this again should the United States adopt a territorial tax system?

To combat the growing concerns of inversions, congress enacted an anti-inversion provision (Section 7874) in the American Jobs Creation Act of 2004 (AJCA; P.L. 108-357). This provision in the act targeted inversions occurring after March 4, 2003. The inverted foreign parent company was treated as a domestic corporation if it is owned by at least $80 \%$ of the former parent's stockholders. That is to say, if the domestic corporation retained $80 \%$ or more interest, it would continue to be tax on worldwide income. If the domestic corporation retains at least $60 \%$ but less than $80 \%$, the new foreign parent company is not tax like a domestic corporation but any U.S. taxes on gain from asset transfers are not permitted to benefit from foreign tax credit or net operating losses (NOLs). Inversions that were created through substantial economic activity in foreign countries were exempted from the anti-inversions provisions. Prior to AJCA of 2004, the U.S. Treasury had defined substantial business activity as being $10 \%$ of worldwide activity. Failure to define what constitutes substantial business activity in AJCA of 2004 thus created the exploration and exploitation of another loophole.

Post 2004, corporations continued to invert via the business activity exemption and mergers with large foreign corporations. In response, Treasury Regulations (T.D. 9592, June 12, 2012) increased the safe harbor for the substantial business activities test from $10 \%$ to $25 \%$, effectively closing off this avenue in the future. ${ }^{\mathrm{v}}$ The Treasury continues to regulate inversions loopholes; an example of their efficiency is closing the loophole that allowed Liberty Global shareholders to avoid paying some capital gains taxes. ${ }^{\mathrm{vi}}$ Despite strong regulations, corporations continue to use mergers has the new vehicle for inversions.

On September 22, 2014, the U.S. Department of Treasury released a fact sheet on the "Treasury Actions to Rein in Corporate Tax Inversions." The summary of that release was:

The culture of corporate tax inversions will be monitor in the future. In recognizing the fact that most parent corporations with subsidiaries in foreign countries have circumvented paying their fair share of taxes, actions are being taken to minimize this practice. The appeal of having controlled foreign corporations (CFCs) will diminish based on the new guidelines. In the past, profits of any foreign company were not recognized as taxable income until a dividend was paid to the U.S. based parent; this is about to change.

Corporations previously made loans to affiliated foreign parent companies directly from their CFCs in a deliberate attempt to evade paying taxes. Previously, the structure of this type of transaction was not consider property of the U.S. However, going forward any such loans will be considered "U.S. Property," and thereby taxable as soon as any transaction of this nature occurs.

Other strategies employed includes, restricting CFCs or reshuffling the controlling interest away from the U.S. parent and therefore facing the tax consequences. The treasury has responded by putting new legislature in place. These new regulations will prevent reshuffling and keep the U.S. parent percentage at $20 \%$ or below. These actions will decrease the practice of allowing the (CFCs) to be adopted by a new foreign parent. It will also counteract the cheating process with regards to evasion. In essence, the prior years of allowing U.S. corporations to channel a 
major portion of their profits to foreign entities and then find different avenues to defer their income, or avoid payment of taxes altogether will soon come to a halt. The U.S. Treasury is continuing to examine new ways to counteract the practice of tax evasion.

More insight to the actions by the Treasury Department to end corporate inversions can be found in the tax code under:

- Section 956(e):

$\circ \quad$ To prevent inverted companies from accessing a foreign subsidiary's earnings while deferring U.S. tax by creative loans, which are known as "hopscotch" loans.

- Section 7701(l):

- To prevent inverted companies from restructuring a foreign subsidiary in order to access the subsidiary's earnings tax-free.

- Section 304(b) (5) (B):

$\circ$ This section deals with closing the loophole to prevent inverted companies from transferring cash or property from a CFC to the new parent to completely avoid U.S. tax.

\section{- Section 7874:}

- Limit the ability of companies to count passive assets that are not part of the entity's daily business functions in order to inflate the new foreign parent's size and therefore evade the 80 percent rule - known as using a "cash box.

$\circ$ To prevent U.S. companies from reducing their size pre-inversion by making extraordinary dividends.

- To prevent a U.S. entity from inverting a portion of its operations by transferring assets to a newly formed foreign corporation that it spins off to its shareholders, thereby avoiding the associated U.S. tax liabilities, a practice known as "spin version."

On January 20, 2015, the Ways and Means Committee proposed new legislation, "Stop Corporate Inversion Act of 2015." This new legislation would tighten the loopholes for inversions, and save an estimated 34 billion in tax revenues, according to the Joint Committee on Taxation.

\section{CPAs Roles in Corporate Inversions}

Despite the type of corporate inversion practice by U.S. corporations, CPAs play a significant role in the decision making process, as well as the transitional process. Domestic corporations rely on their estimates and knowledge of tax implications while considering inversion as an option to the firm. Over the last two years, great concerns and focus are placed on regulating inversion practices, and addressing whether corporations' actions have elements of tax avoidance or tax evasion. The thin line or grey area that exist between the two needs to be differentiated by knowledgeable tax accountants and/or legal minds as they offer tax and consultancy services to their clients.

During 2014, many proposals and bills have surfaced in congress to tighten regulation on inversion practices and therefore, CPAs are required to better educate themselves with the evolving of legislation that may significantly impact their clients financially. For example, while on the surface migrating to lower corporate tax jurisdictions may seem prudent, the CPA must take into account the tax implications that his client may incur domestically with new legislation. Such as capital gain taxes, restrictions on foreign tax credits, limitations on NOLs, limitations of interest deductions and income stripping elements. In actuality, if these elements are not taken into consideration, the CPA firm can actually cause their clients to incur a larger tax liability globally than initially anticipated. Understanding current tax legislation is very important for CPAs because they can be found culpable of encouraging clients with tax evasion practices. That is any CPA's worst nightmare, to have his/her credibility shattered or questioned.

\section{CONCLUSION}

Since the Tax Reform Act of 1986, there has been no major tax reform to the United States Tax System. That's almost 30 years ago; when corporate tax rate was reduce from 48\% to 34\%. The 1993 Tax Act increased the rate to $35 \%$. Since then, many countries reform and restructured their tax system in such a way, that they are attracting more capital investment. 
The business arenas will continue to support corporate inversions, to bypass the U.S. "tax-axe." From a business prospective, corporate inversions are nothing less than prudent, innovative, business strategies to enhance corporate profits. However, it's undoubtedly having a significant impact on U.S. tax revenues and ultimately reducing domestic investments.

Despite the various proposals and recommendations made to address this growing economic issue, all concerns parties have agreed in sorts to revamping the U.S. Tax System. How and when that is done, is totally unclear, for many that call for reform are not willing to pay the cost associated with it. The Treasury Department has responded with new rules to tighten regulations on corporate inversions practices.

Despite the apparent migration through inversion, many of these domestic corporations actually do not shift economic activity, capital, or employment from the United States (at least in the early years). They continued to maintain headquarters in the U.S.A and enjoy the benefits of tax revenues paid by other domestic corporations. While it is true that inversions are not new to the American economy, in the last decade it has become more prevalent. One major impact created by inversion is the reduction in corporate revenue stream, and a larger budget deficit. Such practices have raised concerns about the fairness of the U.S. tax system, erosions of U.S. tax base, and the unpatriotic element. Discussions on these issues continued to stir, as lawmakers and economist weights in on actionable solutions to control and detour this "mania" corporate inversion.

\section{AUTHOR BIOGRAPHY}

Joel Barker, MS, CPA, is an Assistant Accounting Professor at Borough of Manhattan Community College, CUNY, New York, New York, USA. He received his tertiary education through CUNY colleges. He has taught within the CUNY system at Colleges such as, Queens College and York College. Prior to entering academia, his professional experiences were in Public Accounting with the specific focus on audits and taxes. E-mail: jbarker@bmcc.cuny.edu

\section{REFERENCES}

Bloomberg Business. (2015, April 13). Tracking Tax Runaways: Where Corporate Expatriate Have Gone. Retrieved from: http://www.bloomberg.com/infographics/2014-09-18/tax-runaways-tracking-inversions.html

Bloomberg Business. (2014, May 4). While Companies Shift Addresses to Tax Havens, CEO's Stay Put. Retrieved from: http://www.bloomberg.com/infographics/2014-05-04/companies-shift-addresses-abroad.html

Douglas, D., (2014, August 6). American companies that have incorporated overseas. Retrieved from: http://apps. washingtonpost.com/g/page/business/american-companies-that-have-incorporated-overseas/1238/

Ensco-Pride International Inc. (2011, April 25). Joint Proxy Statement, "Recommendation of the Pride Board of Directors and Its Reasons for the Merger," Retrieved from: http:/www.sec.gov/Archives/edgar/data/314808/000095012311039244/ d80026b3e424b3.htm

Hanson, J., Krakower, H., Mataloni Jr., R., Pinard, K. (2015, February). BEA BRIEFING: The Effects of Corporate Inversions on the International and National Economic Accounts. Retrieved from:http://www.bea.gov/scb/pdf/2015 /02\%20February $/ 0215$ corporate_inversions_and the international_and\%20national_accounts.pdf

Huang, C., Marr, C., Friedman, J. (2013, January 13). The Fiscal and Economic Risks of Territorial Taxation. Retrieved from: http://www.cbpp.org/files/1-31-13tax.pdf

Information Station. (2014, August 29). How Corporate Inversions Affect You: Burger King's whopper of a move to Canada shines light on corporate inversions. Retrieved from: http://informationstation.org/kitchen_table_econ/how-corporateinversions-affect-you

Macey, M., (2015, January 23). In Case You Missed It: Secretary Lew's Remarks on the State of the Economy and Business Tax Reform. Retrieved from: http://www.treasury.gov/connect/blog/Pages/In-Case-You-Missed-It---SecretaryLew $\%$ E2\%80\%99s-Remarks-on-the-State-of-the-Economy-and-Business-Tax-Reform.aspx

Maples, D., \& Gravelle, J. (2014, May 27). Corporate Expatriation, Inversions, and Mergers: Tax Issues. Retrieved from: https://www.fas.org/sgp/crs/misc/R43568.pdf

McKinnon, J., \& Thurm, S. (2012, August 28). U.S. Firms Move Abroad to Cut Taxes: Despite '04 Law, Companies Incorporate Overseas, Saving Big Sums on Taxes. Wall Street Journal. Retrieved from: http://www.wsj.com/articles/ SB10000872396390444230504577615232602107536

Pomerleau, K., (2014, August 4). Everything You Need to Know About Corporate Inversions. Retrieved from: http://taxfoundation.org/blog/everything-you-need-know-about-corporate-inversions

Reuters. AM New York. (2015, February 2). Tax Proposed on foreign earnings. Pg.6 
Rubin, R., Baigorri, M., and David, R. (2014, September 24). Pfizer Seeking Inversions Shows Companies Unfazed by Lew. Retrieved from: http://www.bloomberg.com/news/articles/2014-09-24/pfizer-pursuing-inversions-shows-companiesundeterred-by-lew

Sidley Austin LLP (2014, April 29). IRS Aims at Innovative M\&A Inversion Structure. Retrieved from: http://www.sidley.com/ /media/files/news/2014/04/irs-aims-at-innovative-ma-inversion-structure/files/view-update-inpdf-format/fileattachment/tax-update--042914.pdf

The New York Times. (November 24, 2015). Pfizer's Big Breakthrough: Global Tax Avoidance. Retrieved from: http://www.nytimes.com/2015/11/24/opinion/pfizers-big-breakthrough-global-tax-avoidance.html?_r=0

Toder, E. (2013, April 5). Should the US adopt a territorial tax system? Retrieved from: http://www.csmonitor.com/Business/Tax-VOX/2013/0405/Should-the-US-adopt-a-territorial-tax-system

U.S. Congress, Joint Committee on Taxation. (2014, February 26). JCX-15-14. Technical Explanation of the Tax Reform Act of 2014, A Discussion Draft of the Chairman of the House Committee on Ways and Means to Reform the Internal Revenue Code: Title IV-Participation Exemption System for the Taxation of Foreign Income. Retrieved from: https://www.jct.gov/publications.html?func=startdown\&id=4557

U.S. Department of Treasury. (2014, September 22). Press Center: Fact Sheet: Treasury Actions to Rein in Corporate Tax Inversions. Retrieved from: http://www.treasury.gov/press-center/press-releases/Pages/j12645.aspx

Walker, J. (2014, July 14). U.S. Stands to Lose Billions From Corporate Tax Inversions. Retrieved from: http://www.wsj.com/articles/u-s-stands-to-lose-billions-from-corporate-tax-inversions-1405373537

Ways and Means Committee Democrats. (n.d.). H.R. 415: Stop Corporate Inversions Act of 2015. Retrieved from: http://democrats.waysandmeans.house.gov/bill/hr-415-stop-corporate-inversions-act-2015

Wells, B., (2012, July 23). Cant and the Inconvenient Truth About Corporate Inversions. Retrieved from: http://papers.ssrn.com/sol3/papers.cfm?abstract_id=2120861 


\section{ENDNOTES}

${ }^{i}$ Ensco-Pride International Inc. Joint Proxy Statement, "Recommendation of the Pride Board of Directors and Its Reasons for the Merger," April 25, 2011, http://www.sec.gov/Archives/edgar/data/314808/000095012311039244/ d80026b3e424b3.htm.

${ }^{i i}$ More information on the tax treatment of subpart F income may be found in Sections 951 to 956 of the IRC.

iii Monday, February 2, 2015; amNewYork newspaper; "Tax Proposed on foreign earnings"

iv Secretary Lew's Remarks on the State of the Economy and Business Tax Reform by Macey Matthews; URL: http://www.treasury.gov/connect/blog/Pages/In-Case-You-Missed-It---Secretary-Lew\%E2\%80\%99s-Remarks-onthe-State-of-the-Economy-and-Business-Tax-Reform.aspx

${ }^{\mathrm{v}}$ Bret Wells, "Cant and the Inconvenient Truth about Corporate Inversions." Tax Notes, July 23. 2012, pp. 429-439; Kristen A. Parillo, "Government Defends Business Activities Test in New Regs." Tax Notes, July 23, 2012, pp. 370371.

vi IRS Notice 2014-14. See "IRS Aims at Innovative M\&A Inversion Structure," Sidley Austin LLP, at http://m.sidley.com/04-29-2014-Tax-Update/. 